\title{
Alien interference: disruption of infochemical networks by invasive insect herbivores
}

Desurmont, Gaylord A ; Harvey, Jeff ; van Dam, Nicole M ; Cristescu, Simona M ; Schiestl, Florian P ; Cozzolino, Salvatore ; Anderson, Peter ; Larsson, Mattias C ; Kindlmann, Pavel ; Danner, Holger ; Turlings, Ted C J

\begin{abstract}
Insect herbivores trigger various biochemical changes in plants, and as a consequence, affect other organisms that are associated with these plants. Such plant-mediated indirect effects often involve herbivore-induced plant volatiles (HIPVs) that can be used as cues for foraging herbivores and their natural enemies, and are also known to affect pollinator attraction. In tightly co-evolved systems, the different trophic levels are expected to display adaptive response to changes in HIPVs caused by native herbivores. But what if a new herbivore invades such a system? Current literature suggests that exotic herbivores have the potential to affect HIPV production, and that plant responses to novel herbivores are likely to depend on phylogenetic relatedness between the invader and the native species. Here we review the different ways exotic herbivores can disrupt chemically mediated interactions between plants and the key users of HIPVs: herbivores, pollinators, and members of the third (i.e. predators and parasitoids) and fourth (i.e. hyperparasitoids) trophic levels. Current theory on insect invasions needs to consider that disruptive effects of invaders on infochemical networks can have a short-term impact on the population dynamics of native insects and plants, as well as exerting potentially negative consequences for the functioning of native ecosystems.
\end{abstract}

DOI: https://doi.org/10.1111/pce.12333

Posted at the Zurich Open Repository and Archive, University of Zurich

ZORA URL: https://doi.org/10.5167/uzh-96076

Journal Article

Accepted Version

Originally published at:

Desurmont, Gaylord A; Harvey, Jeff; van Dam, Nicole M; Cristescu, Simona M; Schiestl, Florian P; Cozzolino, Salvatore; Anderson, Peter; Larsson, Mattias C; Kindlmann, Pavel; Danner, Holger; Turlings, Ted C J (2014). Alien interference: disruption of infochemical networks by invasive insect herbivores. Plant, Cell Environment, 37(8):1854-1865.

DOI: https://doi.org/10.1111/pce.12333 


\section{Alien interference: Disruption of infochemical networks by invasive \\ insect herbivores}

3

4 Gaylord A. Desurmont ${ }^{1^{*}}$, Jeff Harvey ${ }^{2}$, Nicole M. van Dam ${ }^{3}$, Simona Cristescu ${ }^{4}$, Florian P. Schiestl ${ }^{5}$, 5 Salvatore Cozzolino ${ }^{6}$, Peter Anderson ${ }^{7}$, Mattias C. Larsson $^{7}$, Pavel Kindlmann ${ }^{8}$, Holger Danner ${ }^{3}$,

6 Ted C.J. Turlings ${ }^{1}$

7

$8{ }^{1}$ Institute of Biology, University of Neuchâtel, Neuchâtel, Switzerland

$9{ }^{2}$ Terrestrial Ecology, Netherlands Institute of Ecology, Wageningen, The Netherlands

$10{ }^{3}$ Ecogenomics, Radboud University Nijmegen, Nijmegen, The Netherlands

$11{ }^{4}$ Institute for Molecules and Materials, Radboud University Nijmegen, Nijmegen, The Netherlands

$12{ }^{5}$ Institut für Systematische Botanik, University of Zurich, Zurich, Switzerland

$13{ }^{6}$ Dipartimento di Biologia, Università degli Studi di Napoli Federico II, Napoli, Italy

14 'Plant Protection Biology, Swedish University of Agricultural Sciences, Alnarp, Sweden

$15{ }^{8}$ Institute for Environmental Studies, Charles University, Prague, Czech Republic

16

17

$18 *^{*}$ Corresponding author:

19 Gaylord A. Desurmont, Institute of Biology, University of Neuchâtel, Rue Emile-Argand 11, CH-2000

20 Neuchâtel, Switzerland, gaylord.desurmont@unine.ch

21

22

23

24 Running Title: Invasive insects and infochemicals

This article has been accepted for publication and undergone full peer review but has not been through the copyediting, typesetting, pagination and proofreading process, which may lead to differences between this version and the Version of Record. Please cite this article as doi: 10.1111/pce.12333

This article is protected by copyright. All rights reserved. 
Insect herbivores trigger various biochemical changes in plants and, as a consequence,

29 affect other organisms that are associated with these plants. Such plant-mediated

30 indirect effects often involve herbivore-induced plant volatiles (HIPVs) that can be used

31 as cues for foraging herbivores and their natural enemies, and are also known to affect

32 pollinator attraction. In tightly co-evolved systems, the different trophic levels are

33 expected to display adaptive response to changes in HIPVs caused by native herbivores.

34 But what if a new herbivore invades such a system? Current literature suggests that

35 exotic herbivores have the potential to affect HIPV production, and that plant responses

36 to novel herbivores are likely to depend on phylogenetic relatedness between the

37 invader and the native species. Here we review the different ways exotic herbivores can

38 disrupt chemically mediated interactions between plants and the key users of HIPVs:

39 herbivores, pollinators, and members of the third (i.e. predators and parasitoids) and

40 fourth (i.e. hyperparasitoids) trophic levels. Current theory on insect invasions needs to

41 consider that disruptive effects of invaders on infochemical networks can have a short

42 term impact on the population dynamics of native insects and plants, as well as exerting

43 potentially negative consequences for the functioning of native ecosystems.

44

45 Key-words: invasive species, plant volatiles, multitrophic interactions, plant-insect

46 interactions

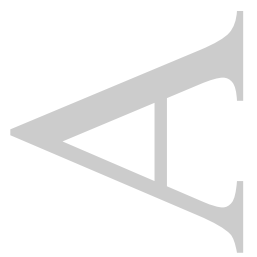




\section{INTRODUCTION}

49

Plant volatiles are of key importance for the foraging behaviour of many insects.

51 Pollinators, for example, use plant-produced volatiles to locate rewarding flowers

52 (Pichersky \& Gershenzon, 2002, Raguso, 2008, Schiestl, 2010). In contrast to these

53 mutualists, many herbivores utilize plant volatiles to identify suitable host plants

54 (Bruce, Wadhams \& Woodcock, 2005). Of particular interest is the phenomenon that

55 plants under attack by arthropod herbivores show dramatic increases in the production

56 of specific volatiles. Certain herbivores are deterred by these inducible volatiles (De

57 Moraes, Mescher \& Tumlinson, 2001, Kessler \& Baldwin, 2001), possibly to avoid

58 competition, reduced food quality, or natural enemies, but others are attracted to

59 already infested plants (Heil, 2004, Horiuchi, Arimura, Ozawa, Shimoda, Dicke,

60 Takabayashi \& Nishioka, 2003), in certain cases to initiate mass attacks on weakened

61 hosts (Raffa, Phillips \& Salom, 1993).

62 Inducible plant volatiles are also of great importance to predators and

63 parasitoids in search of prey or hosts. Therefore, herbivore-induced plant volatiles

64 (HIPVs) are proposed to function as a form of indirect resistance that relies on the third

65 trophic level to reduce herbivore damage (Dicke \& Sabelis, 1988, Turlings, Tumlinson \&

66 Lewis, 1990). This indirect defensive function is still highly debated (Allison \& Hare,

67 2009, Arimura, Matsui \& Takabayashi, 2009, Hare, 2011, Heil \& Karban, 2010,

68 Holopainen, 2004, Peñuelas \& Llusià, 2004), but there is an overall consensus that

69 arthropods at different trophic levels use plant volatiles to locate key resources and that

70 these chemically-mediated interactions may be very specific, with each species having

71 evolved to exploit particular volatile blends. We propose that invading insect herbivores

This article is protected by copyright. All rights reserved. 
72 may disrupt these finely-tuned chemically mediated interactions and that this may have

73 consequences for the reproductive success and eventually the population structure of

74 the interacting native plants and insects.

With increasing globalization, many plants and animals are being accidentally or

76 intentionally introduced into non-native ecosystems, and some of these invaders pose

77 major threats for biodiversity and the functioning of ecological processes in their

78 introduced range (Gandhi \& Herms, 2010, Vilà, Espinar, Hejda, Hulme, Jarošík, Maron,

79 Pergl, Schaffner, Sun \& Pyšek, 2011). Moreover, recently observed changes in climate

80 that are driven largely by humans are also challenging species to adapt and many are

81 responding by moving polewards. The consequences of these invasions have been

82 studied extensively, but very little attention has been given to many important

83 mechanisms involved, such as plant odour-mediated interactions (Gandhi \& Herms,

84 2010, Kenis, Auger-Rozenberg, Roques, Timms, Péré, Cock, Settele, Augustin \& Lopez-

85 Vaamonde, 2009). In the context of a EUROCORE project we recently launched a

86 collaborative effort to study this concept of alien herbivores interfering with

87 infochemical networks (Fig. 1). We particularly focus on quantifying the effects of

88 invasive insect herbivores on the foraging behaviour of native herbivores and plant

89 mutualists, such as pollinators and parasitic wasps. To our knowledge, no study has

90 specifically addressed this issue, but a number of investigations on the interactions

91 among assemblages of native arthropods (Bukovinszky, Poelman, Kamp, Hemerik,

92 Prekatsakis \& Dicke, 2012), or between native arthropods and invasive plants (Harvey \&

93 Fortuna, 2012) strongly suggest that the disruption of plant-odour mediated

94 interactions can have ecological consequences (Table 1). Within this framework, a key

95 point to address is whether and how the effects of exotic herbivores on HIPVs differ

96 from effects caused by native herbivores. Indeed, native species can also play the role of 
97 "info-disrupter" in interactions within native communities. For example, the effect of

98 Mamestra brassicae, a Eurasian moth, on the volatiles emitted by crucifers was shown to

99 influence the outcome of the interactions between another native herbivore, Pieris

100 brassicae, and its parasitoid Cotesia glomerata (Bukovinszky et al., 2012). Thus,

101 demonstrating that invasive species have an impact on infochemical networks may not

102 be a sufficient conclusion: the ultimate ecological challenge is to determine whether or

103 not the impact of invaders is greater than or different from the impact naturally caused

104 by other members of the native fauna, and poses a greater threat to the functioning of

105 native ecosystems. In this context, a comparative approach would be most appropriate.

106 Studying single pairs of organisms (one native species/one exotic species) may be a

107 valuable approach in a specific context, for example predicting the outcome of the

108 association between a threatening invasive species and a particularly rare or

109 ecologically important native species. However, to reveal general ecological trends and

110 to answer the question of the global impact of invasive species on infochemical

111 networks, a standardized comparison of the effects of several native and exotic species

112 on chemically mediated interactions will be necessary.

113

Two fundamental questions pertain to the notion of interference of chemically

114 mediated interactions by invasive insect herbivores: 1) how do plants perceive and

115 respond to "novel" herbivory? And 2) are insects that rely on infochemical networks

116 adapted to variations in HIPVs and able to cope with those induced by invasive

117 herbivores? Here we combine our current knowledge of biochemical mechanisms

118 involved in the production of plant volatiles and recent invasion biology literature to

119 unite/bridge both questions. Then, we address the question of adaptation to variation in

120 HIPVs for each of the trophic levels involved in infochemical networks: herbivores, 
121 natural enemies of herbivores (third trophic level) and their own natural enemies (i.e.

122 hyperparasitoids, fourth trophic level), and pollinators.

123

124 HOW DO PLANTS PERCEIVE AND RESPOND TO “NOVEL” HERBIVORY?

125

126 The notion of novel herbivory, hereby defined as feeding by an herbivore that the plant

127 has not experienced over evolutionary time, is relative. Due to the immense variety of

128 herbivores attacking plants worldwide and the diversity of feeding strategies they

129 occupy, the possibility of an invasive insect attacking and damaging native plants in an

130 entirely novel way is unlikely. Geographically isolated environments, such as islands,

131 where plants could have existed in absence of some specific guilds of herbivores

132 (Reaser, Meyerson, Cronk, De Poorter, Eldrege, Green, Kairo, Latasi, Mack \&

133 Mauremootoo, 2007), may be an exception to that rule, but in the vast majority of exotic

134 insects invasions, the invader will become an additional species integrated into native

135 plant-insect food webs. Still, the scenario of an invasive species attacking native plants

136 in the exact same way as a native herbivore is equally unlikely, because modes of

137 feeding vary tremendously from species to species. Preferences for specific plant tissues

138 or organs, feeding patterns, activity rhythms and circadian cycles, solitary or gregarious

139 feeding behaviours, chemistry of saliva, and counter-adaptations to plant defences are

140 among the many parameters that potentiate species-specific variation. In other words,

141 all exotic herbivores are expected to have some "elements of novelty", i.e. diverge from

142 existing native herbivores in some specific traits, but none, or very few, will pose an

143 entirely new threat to native plants. The true question is to know which herbivore traits

144 are fundamental to the perception by the plant of herbivory and its response in the form 
145 of a volatile blend emitted upon attack, and how these traits are expected to differ

146 between native and exotic herbivores.

147

148 Herbivore cues recognized by plants

149 In order to investigate whether or not plant responses to exotic herbivores may differ

150 from responses to native herbivores, we must first understand how plants perceive

151 herbivorous arthropods, a topic that has been the subject of several recent reviews

152 (Hilker \& Meiners, 2010, Mithöfer \& Boland, 2012, Mumm \& Dicke, 2010, Wu \& Baldwin,

153 2010). It is well known that plants typically produce different blends of HIPVs when

154 damaged by insects compared to plants that are merely mechanically wounded,

155 implying the existence of insect-derived compounds (including plant compounds

156 modified by insect enzymes) responsible for initiating specific plant responses. Such

157 elicitors have been discovered in insect oral secretions for several systems (Pare, Farag,

158 Krishnamachari, Zhang, Ryu \& Kloepper, 2005, Tumlinson \& Engelberth, 2008).

159 Additionally, plants can perceive other types of insect cues, related to touch (Hall,

160 MacGregor, Nijsse \& Bown, 2004), or associated with oviposition (Reymond, 2013).

161 Plant responses to oviposition-related elicitors range from direct defence [e.g. necrosis,

162 growth of undifferentiated wound tissue (Balbyshev \& Lorenzen, 1997, Desurmont \&

163 Weston, 2011)] to the production of specific HIPV blends attractive to natural enemies

164 (Fatouros, Bukovinszkine’Kiss, Dicke \& Hilker, 2007).

165 While critical for plant responses, biochemical elicitors do not constitute the only

166 facet of herbivory. The type of damage inflicted to the plant is also known to influence

167 the production of plant volatiles. Sucking piercing insects such as aphids induced

168 different responses than chewing insects such a caterpillars (Bidart-Bouzat \&

169 Kliebenstein, 2011). Also the location (i.e. organ attacked) and the "physical

This article is protected by copyright. All rights reserved. 
170 characteristics" (e.g. scratching, chewing, or skeletonizing damage for leaf-feeders) of

171 the damage may matter and result in the production of distinct blends of HIPVs

172 (Mithöfer \& Boland, 2008, Pierre, Jansen, Hordijk, van Dam, Cortesero \& Dugravot,

173 2011). This matter is complicated by the fact that feeding habits can be plastic and

174 change over the lifetime of an herbivore, as illustrated by P. brassicae caterpillars, which

175 are typically leaf feeders but switch to flower-feeding during their development on

176 Brassica nigra (Smallegange, Van Loon, Blatt, Harvey, Agerbirk \& Dicke, 2007). Finally,

177 plants can respond to the time course and circadian rhythm of herbivory (Arimura,

178 Köpke, Kunert, Volpe, David, Brand, Dabrowska, Maffei \& Boland, 2008, Connor, Rott,

179 Samietz \& Dorn, 2007, Mithöfer, Wanner \& Boland, 2005). These results suggest that the

180 production of specific volatile blends in response to herbivory can be, in certain cases,

181 independent of the presence of elicitors in oral secretions. However, from the plant's

182 perspective, feeding habits may be less reliable of the identity of an attacker than

183 biochemical elicitors due to their potentially variable and dynamic nature.

184 In summary, we postulate that the volatile blend produced by a plant in response

185 to herbivory can depend on three herbivore-dependent variables: 1) the type of elicitors

186 associated with the herbivore, 2) the type and location of damage inflicted to the plant,

187 and 3) the time course or rhythm of herbivory. Because tremendous variation in these

188 traits exists among potential invasive insect herbivores, making general predictions

189 about the extent to which plant responses to exotic and native herbivores may differ in

190 general is a seemingly impossible task. Practically, in order to predict how a plant will

191 respond to a given exotic species, it is necessary to examine where the novel herbivore

192 is situated within this space of the tripartite herbivory traits, or, in other words,

193 determine its coordinates on a three-dimensional "herbivory map", and compare these

194 coordinates to those of the assemblage of native herbivores associated with the plant.

This article is protected by copyright. All rights reserved. 
195 This trait-matching approach has been used in invasion biology studies, mainly in the

196 context of predicting the native species of herbivores most likely to feed on an exotic

197 plant, and evaluating the risks of non-target effects on native plants following the

198 introduction of a biological control agent of an exotic plant (Pearse, Harris, Karban \& Sih,

199 2013). However, the principal limitation of such approaches is the lack of detailed

200 information available on the traits that matter in the context of a specific interaction. To

201 overcome this obstacle, phylogenetic relatedness has been commonly used as a proxy

202 for similarity in traits or groups of traits between native and exotic species of plants or

203 herbivores (Becerra, 1997, Gilbert, Magarey, Suiter \& Webb, 2012).

204 At a broad scale, related plant species may have similar defensive responses, and

205 exotic herbivore species closely related to native ones may share similar feeding habits.

206 Interestingly, a phylogenetically controlled comparative study of elicitors of plants

207 defences (FACs) showed that closely related species indeed have more elicitors in

208 common than species that are distantly related (Mori \& Yoshinaga, 2011, Yoshinaga,

209 Alborn, Nakanishi, Suckling, Nishida, Tumlinson \& Mori, 2010), suggesting evolutionary

210 conservatism of these cues. However, it remains largely unknown how different

211 assemblages of FACs interact and ultimately affect plant response for most herbivores.

212 In the context of understanding interference effects due to exotic herbivores on

213 infochemical networks, we speculate that the use of phylogenetic tools may be useful to

214 estimate the likelihood of an herbivore or a plant to possess certain traits, but will have

215 limited power to predict the outcome of a novel insect-plant interaction in terms of

216 production of specific plant volatiles after attack, and even less so how these volatiles

217 may interfere in the existing native interactions.

218

219 Conceivable plant responses elicited by exotic herbivores.

This article is protected by copyright. All rights reserved. 
221 Alternatively to a predictive, trait-matching approach, a more pragmatic approach may

222 be taken to address the apparent "Pandora's box" of plant responses to novel

223 herbivores. In the light of our knowledge of plant perception of herbivory, what general

224 types of response can we expect from a plant in terms of divergence from its response to

225 native herbivores? Intuitively, we can think of three possible types of response (Fig. 2):

226 (1) The null response. The plant damaged by the exotic herbivore does not release

227 volatiles that differ qualitatively or quantitatively from a mechanically wounded plant.

228 This type of response is most likely to occur if the novel herbivore lacks the chemical

229 elicitors present in the oral secretions of native herbivores. Examination of the elicitors

230 present in a range of lepidopteran herbivores revealed that the most common elicitors

231 (i.e. FACs structurally similar to volicitin) are not present in several species, supporting

232 this notion (Yoshinaga et al., 2010). In a controlled context, comparing the volatile

233 blends emitted in response to plants mechanically wounded with and without oral

234 secretions of the exotic species may be a good way to check whether the plant "reacts" to

235 the novel herbivore. However, given the fact that repeated periodical wounding of a

236 plant can be sufficient to elicit a response different from one-time mechanical damage

237 (Mithöfer et al., 2005), the null response may be hard to define under natural herbivore

238 damage conditions.

239 (2) The identical response. The plant damaged by the exotic herbivore emits a blend of

240 volatiles that is undistinguishable from the blend produced in response to a native

241 herbivore. This type of response is more likely to occur if the exotic herbivore is closely

242 related to the native herbivore and overlaps largely in terms of biochemical elicitors and 243 feeding habits. 
(3) The novel response. The plant damaged by the exotic herbivore emits a blend that

245 differs to some extent from the blends produced in response to its associated native

246 herbivores. Any type of qualitative or quantitative change in the HIPV blend can

247 theoretically be considered to have an element of novelty: even subtle differences in

248 ratios of volatiles have been shown to impact the foraging behaviour of insects (Bruce et

249 al., 2005, Visser \& Avé, 1978). The limited number of studies documenting induced

250 direct defences of plants in response to exotic herbivores shows that different types of

251 "novel responses" are possible, from reduced defensive response of the plant due to its

252 evolutionary naiveté (Desurmont, Donoghue, Clement \& Agrawal, 2011, Woodard, Ervin

253 \& Marsico, 2012), to an over-sensitive response to a particular herbivore (Radville,

254 Chaves \& Preisser, 2011).

255 The three theoretical types of responses to novel herbivory will have drastically

256 different implications for insect-plant interactions, depending on the type of interactions

257 that the plants have with the native insect (antagonistic or mutualistic), and on the

258 degree to which native insects depend on HIPVs to achieve reproductive success. It is

259 important to keep in mind that the distinction between an "identical" and a "novel"

260 response ultimately depends on the level of chemosensitivity of the receiver, and to the

261 degree of chemical complexity necessary to elicit a behavioural answer. An organism

262 only able to detect (or only looking for) a reduced number of volatiles compounds may

263 not distinguish between plants infested by a native and an exotic herbivore if the

264 differences in HIPVs elicited by both herbivores are minor. On the other hand,

265 organisms known to change their behaviour in response to subtle chemical changes,

266 such as certain parasitic wasps, may be able to make this distinction. In other words, the

267 same HIPVs blend emitted in response to an exotic herbivore may be perceived as an

268 identical response or a novel response by different receivers. 
272 A wide range of insects belonging to different trophic levels and feeding guilds can

273 perceive and make use of plant volatiles induced by herbivory (Dudareva, Negre,

274 Nagegowda \& Orlova, 2006, Hare, 2011), but the extent to which HIPVs can affect their

275 reproductive success varies. For insect herbivores and pollinators, HIPVs may carry

276 information regarding the quality of a plant as a resource (Cunningham, Moore, Zalucki

$277 \&$ West, 2004, Fitt, 1989), which may result in adaptive attraction or deterrence, but

278 herbivores and pollinators do not depend on HIPVs as long as they can locate suitable

279 undamaged plants/flowers by using constitutively released plant volatiles or other cues,

280 e.g. vision or vibration. On the other hand, specialized natural enemies such as parasitic

281 wasps often rely on HIPVs as key foraging cues in detecting the presence of a host insect

282 on a plant (Godfray, 1994, Quicke, 1997): their ability to detect suitable hosts ultimately

283 determines their fitness. Indeed, parasitoids have been shown to possess a very strong

284 innate propensity to respond to HIPVs (Vet, Lewis \& Carde, 1995), as well as a strong

285 capacity to learn novel odours (Turlings, Wäckers, Vet, Lewis \& Tumlinson, 1993). Thus,

286 some groups of insects have been under a stronger selective pressure to detect and

287 respond to HIPVs than others, and these groups are at a greater risk to be significantly

288 affected by disturbances in infochemicals caused by invasive herbivores. The other side

289 of that coin is that insects that rely the most on HIPVs are also the most likely to have

290 evolved adaptive responses to variation in HIPVs naturally occurring in their

291 environment. For example, parasitic wasps may benefit from being able to find their

292 hosts on plants growing under a range of environmental conditions, and thus to be

293 adapted to variation in volatiles resulting from plant responses to different abiotic 
294 conditions (Chen, Schmelz, Wäckers \& Ruberson, 2008, Gouinguené \& Turlings, 2002,

295 Winter \& Rostás, 2010). Such adaptations could theoretically make them more "robust"

296 to potential disturbance effects caused by invaders. In the following sections, we review

297 the possible ecological consequences of HIPVs interferences for insects belonging to the

298 different trophic levels involved in infochemical networks, and discuss their potential

299 for adaptation to these disturbances.

300

301 INSECT HERBIVORES

302

303 Host plant location and acceptance by insect herbivores is typically performed by

304 females, and plant chemistry plays an important role in these foraging efforts (Bernays

305 \& Chapman, 1994), not only aboveground but also belowground (Johnson \& Nielsen,

306 2012). Detection of a suitable host-plant may depend on the recognition of specific

307 chemical compounds (Blight, Pickett, Wadhams \& Woodcock, 1995, Nottingham, Hardie,

308 Dawson, Hick, Pickett, Wadhams \& Woodcock, 1991), or of specific ratios of compounds

309 (Visser \& Avé, 1978). Many herbivore species prefer healthy unharmed plants of the

310 appropriate species, but others prefer to deposit their eggs on plants that have already

311 been damaged by conspecifics (Desurmont \& Weston, 2011, Raffa et al., 1993) or

312 heterospecific herbivores (Poelman, Broekgaarden, Van Loon \& Dicke, 2008, Shiojiri,

313 Takabayashi, Yano \& Takafuji, 2002). The use of HIPVs may be critical in distinguishing

314 uninfested host plants from infested ones. For example, females of the moth Heliothis

315 virescens are repelled by the emission of (Z)-3-hexenyl acetate and other aliphatic esters

316 of (Z)-3-hexen-1-ol by caterpillar-infested tobacco plants, and prefer to deposit their

317 eggs on unharmed plants (De Moraes et al., 2001). Both attraction to and avoidance of

318 infested plants can be adaptive for herbivores (Eigenbrode, Ding, Shiel \& Berger, 2002),

This article is protected by copyright. All rights reserved. 
319 depending on whether the infested plant becomes more or less susceptible to

320 subsequent herbivory (Agrawal, 2000, Fordyce, 2003, Karban, Agrawal \& Mangel, 1997).

321 Newly invading insects interfering with these volatile cues may lead to

322 maladaptive choices by native herbivores, such as attraction to plants with increased

323 resistance, or the avoidance of perfectly suitable plants. Oviposition "mistakes" (i.e.

324 phytophagous insects laying eggs on unsuitable plants) have received considerable

325 attention in the context of plant invasions (Harvey, Bukovinszky \& van der Putten, 2010,

326 Harvey \& Fortuna, 2012). Indeed exotic plants stimulating oviposition, but not

327 supporting offspring development, have been referred to as "ecological traps" for native

328 herbivores (Keeler \& Chew, 2008). Here we advance the idea that exotic insect

329 herbivores may also lead to suboptimal feeding or oviposition choices and a degradation

330 of preference/performance relationships for native insects due to HIPVs interferences.

331 While such effects may naturally occur between pairs of native species within native

332 communities, we expect invasive exotic herbivores to have a greater disturbance

333 potential due to the lack of evolutionary history between the invader and native species.

334 Indeed native species may have evolved adaptive behavioural responses to HIPVs

335 associated with other native community members, but their responses to "novel" HIPVs

336 that result from unfamiliar herbivory are unpredictable and thus more likely to be

337 maladaptive. Ultimately, the realized fitness of native herbivores in presence and

338 absence of the exotic competitor will determine the strength and direction of the

339 selection imposed on the foraging behaviour of the native species.

The effects of HIPVs interferences on herbivores may extend beyond the infested

341 plant and reach neighbouring plants via plant-plant communication. Indeed, it is known

342 for several systems that plants can perceive and respond to HIPVs emitted by

343 conspecifics (Arimura, Ozawa, Horiuchi, Nishioka \& Takabayashi, 2001) or other plant 
344 species (Karban, 2001), and use these infochemicals to induce or prime their own

345 defences before herbivore attack (Heil \& Karban, 2010, Ton, D'Alessandro, Jourdie,

346 Jakab, Karlen, Held, Mauch-Mani \& Turlings, 2007). Thus, HIPVs interferences have the

347 potential to not only affect the foraging choices of native herbivores, but also, by

348 changing the defence responses in neighbouring plants, affect herbivore performance

349 and dispersal patterns at the patch level.

350 Are herbivores well-adapted to HIPVs variations in nature? It is generally

351 assumed that specialized phytophagous insects have developed more finely-tuned

352 interactions with their host plants, and may thus be capable of more complex or subtle

353 choices when evaluating the quality of a resource. For example, the specialist elm leaf

354 beetle Xanthogaleruca luteola is attracted to lightly infested elm leaves, but not heavily

355 infested leaves (Meiners, Hacker, Anderson \& Hilker, 2005). The same is true for the

356 root-feeding larvae of the maize pest Diabrotica virgifera virgifera, which are attracted

357 to already infested root systems, but not when infestation levels are high (Robert, Erb,

358 Hibbard, French, Zwahlen \& Turlings, 2012). For the viburnum leaf beetle Pyrrhalta

359 viburni, both the magnitude of infestation (quantity of conspecifics' egg masses) and the 360 quality of infestation (number of conspecifics that contributed to the infestation) have

361 an effect on the oviposition preferences of females (Desurmont \& Weston, 2010). On the

362 other hand, generalist insect species are also capable of complex foraging decisions, as

363 illustrated by grasshoppers mixing food sources in order to balance their dietary needs

364 (Behmer, 2008, Behmer \& Elias, 2000). Overall, there is no clear evidence that olfactory

365 receptor neurons, which are the nerve cells used by insects to detect odours, differ in

366 sensitivity or specificity between specialist and generalist insect herbivores (Bruce et al.,

367 2005). Therefore, diet breadth may not be a reliable indicator of how likely herbivores

368 are to be sensitive or adapted to disturbances in HIPVs. In addition to innate preferences 
369 for certain volatiles, herbivores can also learn from previous experiences: food sources

370 experienced as immature insects have been shown to affect the foraging preferences of

371 adults in several systems (Akhtar \& Isman, 2003, Webster, Qvarfordt, Olsson \&

372 Glinwood, 2013). Associative learning may thus help overcoming the potential

373 detrimental effects of the presence of exotic herbivores for native species.

374 A key example of how chemically mediated interactions lead evolutionary

375 trajectories of herbivores in a multitrophic context is given by the two lepidopteran

376 species Plutella xylostella and Pieris rapae, which coexist on crucifer plants. Plants emit a

377 different odour blend in response to damage by each of these herbivores. The parasitoid

378 Cotesia vestalis is attracted by the odours of plants attacked by its host P. xylostella, but

379 not by P. rapae, which is an unsuitable host and which it therefore does not attack.

380 Females of $P$. xylostella appear to take advantage of that fact by preferring plants

381 attacked by P. rapae for oviposition (Shiojiri et al., 2002). These findings illustrate nicely

382 that interference caused by an herbivore (i.e. Pieris rapae) on a volatile-mediated

383 interaction (i.e. foraging behaviour of $C$. vestalis on crucifers) can have fitness

384 consequences for a second herbivore (i.e. Plutella xylostella), leading to selection for an

385 adaptive response to said interference in the long term.

386

387 INSECT POLLINATORS

388

389 Insect-pollinated plants rely on visual and chemical flower signals that help to optimize

390 the attraction of effective pollinators (Fenster, Armbruster, Wilson, Dudash \& Thomson,

391 2004). In many cases, volatiles produced by the flowers play an essential role in

392 attracting pollinators from a distance, and convergent patterns in floral scents have

393 been found among families of flowering plants (Raguso, 2008, Schiestl, 2010). Exotic

This article is protected by copyright. All rights reserved. 
394 herbivores may interfere with this mutualism if the feeding habits of the herbivore (e.g.

395 florivory) directly impact the quality of the floral bouquet, or if plant volatiles emitted

396 after herbivory affect pollinator attraction (Lucas-Barbosa, van Loon \& Dicke, 2011).

397 Direct herbivory on flowers has been demonstrated to affect visits by pollinators in

398 several systems (Lohman, Zangerl \& Berenbaum, 1996, McCall \& Irwin, 2006). On the

399 other hand, the effects of HIPVs emission on pollinator attraction vary: although lower

400 visitation frequency on plants infested by herbivores seems to be the most common

401 scenario (Adler, Karban \& Strauss, 2001, Cardel \& Koptur, 2010, Danderson \& Molano-

402 Flores, 2010, Kessler \& Halitschke, 2009, Kessler, Halitschke \& Poveda, 2011), higher

403 pollinator attraction has also been documented (Poveda, Steffan-Dewenter, Scheu \&

404 Tscharntke, 2003). In wild radishes, uninfested plants were more visited by syrphid

405 flies. This preference could not be linked to morphological features of flowers on

406 infested plants (Lehtilä \& Strauss, 1997), suggesting that avoidance of infested flowers is

407 based on odorous cues. However, in most cases it is unclear whether the effect of HIPVs

408 on pollination is due to a herbivore-induced volatile in the flower (Kessler \& Halitschke,

409 2009) or to the reduction in the amounts of floral scents released by the plant upon

410 herbivory (Kessler, Diezel \& Baldwin, 2010). An interesting aspect is the possible

411 compensation of herbivore-mediate reduction of floral attractiveness. A recent study

412 with Pieris brassicae feeding on Brassica rapa suggests that plants compensate reduced

413 attractiveness due to lower scent emission with the production of more flowers during

414 early flowering (Schiestl et al in press). This compensatory plant response was not

415 evident when the invasive Spodoptera littoralis was feeding on the plant, suggesting

416 stronger fitness impacts of this herbivore-mediated through floral attractiveness to

417 pollinators (Schiestl et al in review). On the long term, a trade-off between defence and

418 reproduction can occur if herbivore-induced volatiles decrease pollination quality, or if

This article is protected by copyright. All rights reserved. 
419 floral odours interfere with the efficiency of volatile-mediated defences (i.e. attraction of

420 herbivore antagonists). The outcome of these interactions for plant fitness will

421 determine the direction of the investment toward reproduction or defence in presence

422 of herbivores (Bartkowska \& Johnston, 2012, Schiestl \& Johnson, 2013).

423 What can we expect from pollinators in terms of adaptation to HIPV variation? As

424 stated in the introduction, HIPVs may carry information about the quality of a resource

425 to pollinators, such as the quality and quantity of the nectar reward (Kessler \&

426 Halitschke, 2007), but pollinators will rarely depend solely on the presence of HIPVs to

427 find flowers. This consideration aside, it is well known that the main groups of generalist

428 pollinators (honey bees, bumblebees) are remarkable learners (Riffell, 2011), using

429 experience-based learning of olfactory and visual cues to exploit the most profitable

430 nectar and pollen sources. They may thus be able to learn quickly whether a plant

431 infested by an exotic species provides higher or lower quality reward compared to

432 uninfested plants, and adjust their foraging preferences in accordance (Wright \&

433 Schiestl, 2009).

434 It is hard to predict which general type of plant response to novel herbivory (null,

435 identical, or novel; Fig 2) is the most likely to have a significant impact on plant-

436 pollinator interactions. We can only state that novel responses are the most likely to

437 affect plant-herbivore-pollinator interactions in the invaded environment.

438

439 INSECTS FROM THE THIRD AND FOURTH TROPHIC LEVELS

440

441 As the third trophic level we consider the natural enemies of arthropods herbivores.

442 They can be separated in two main categories: 1) predators, which feed upon a certain

443 number of prey items during their lifetime, and, 2) parasitic wasps, flies, and a few

This article is protected by copyright. All rights reserved. 
444 species from other orders, also referred to as parasitoids, whose larvae develop on or

445 within eggs, larvae, or adults of insect herbivores, eventually killing their host. Insects

446 belonging to the fourth trophic level are natural enemies of predators and parasitoids.

447 The best-known insects belonging to the fourth trophic level are hyperparasitoids:

448 parasitic wasps that attack the larvae or pupae of primary parasitoids. In general,

449 parasitoids and hyperparasitoids are much more specialized than predators: they can

450 only parasitize a limited number of host species, less than the number of prey species

451 predators can attack. There are of course exceptions to that rule, and generalist

452 parasitoids and specialized predators are not uncommon (Hassell \& May, 1986, Quicke,

453 1997).

454 In the search for prey or hosts, predators and parasitoids utilize cues that are

455 directly associated with the presence of hosts (Colazza, Cusumano, Giudice \& Peri, 2014)

456 such as chemical traces left by insects' tarsi, frass, honeydew, or silk. These cues are

457 thought to be predominantly used for short-range foraging. To detect prey-infested

458 plants from a distance, natural enemies often rely on plant volatiles released locally and

459 systemically after herbivory (Vet \& Dicke, 1992). How reliable are HIPVs as indicators of

460 the presence of specific herbivores on a plant? Reports on the subject (Clavijo

461 McCormick, Unsicker \& Gershenzon, 2012, Dicke, 1999) indicate considerable variation

462 among systems. On one end of the spectrum, some plants release very similar blends of

463 volatiles in response to attacks by insects from different feeding guilds (Kessler \&

464 Baldwin, 2001). On the other end of the spectrum, several plants have been found to

465 release distinct blends of volatiles in response to subtle changes in herbivore attack,

466 such as: developmental stage of the herbivore (Yoneya, Kugimiya \& Takabayashi, 2009),

467 density of herbivores (Girling, Stewart-Jones, Dherbecourt, Staley, Wright \& Poppy,

468 2011, Horiuchi, Arimura, Ozawa, Shimoda, Takabayashi \& Nishioka, 2003), and whether 
469 herbivores have been parasitized or not (Poelman, Zheng, Zhang, Heemskerk, Cortesero

470 \& Dicke, 2011). Such specificity in volatile emission provides reliable information, which

471 can be exploited by parasitoids to optimize their foraging decisions (Poelman et al.,

472 2011). In parallel, hyperparasitoids have recently been found to also use HIPVs to locate

473 their parasitoid hosts. They are able to discriminate not only between plants bearing

474 healthy herbivores and plants bearing parasitized herbivores, but also between plants

475 with herbivores parasitized by their preferred host and plants with herbivores

476 parasitized by a less optimal host (Poelman, Bruinsma, Zhu, Weldegergis, Boursault,

477 Jongema, van Loon, Vet, Harvey \& Dicke, 2012). These fascinating findings demonstrate

478 that specific HIPVs can be exploited not only by natural enemies of insect herbivores,

479 but also by the enemies of these enemies, and illustrate the complexity of HIPV-

480 mediated multitrophic interactions.

In this context, volatiles emitted in response to exotic herbivores can interfere

482 with the foraging behaviour of native insects from the third and fourth trophic levels in

483 two main ways: 1) direct attraction to the plant damaged by the exotic herbivore only,

484 and 2) increased or decreased attraction to plants infested by both the exotic herbivore

485 and the native host or prey. The outcome of these two types of interferences on the

486 fitness of predators/parasitoids/hyperparasitoids will also depend on whether the

487 exotic herbivore can be successfully attacked or not. Exotic herbivores that cannot be

488 attacked (=non hosts) constitute a 'dead end' for native natural enemies, and the

489 attraction to plants infested by these non-hosts may be costly in time and energy. Such

490 attraction to non-host infested plants has been documented for native parasitoids

491 (Snoeren, Mumm, Poelman, Yang, Pichersky \& Dicke, 2010). On the other hand, exotic

492 herbivores that can be attacked may not negatively affect natural enemies through

493 volatile attraction, but may allow native herbivores to escape predation/parasitism. The

This article is protected by copyright. All rights reserved. 
494 consequences of multiple herbivory (here, plants doubly infested with the native and

495 the exotic herbivore) for parasitoids are much harder to predict and will be highly

496 system-specific. This topic has been the subject of a recent review (de Rijk, Dicke \&

497 Poelman, 2013).

498 A recent study on the attraction of the predatory mite Phytoseiulus macropilis

499 (Banks) illustrates how an uncommon herbivore can interfere with a chemically-

500 mediated tritrophic interaction (Fadini, Venzon, Oliveira, Pallini \& Vilela, 2010). It was

501 found that the predator was strongly attracted to plants with the spider mite

502 Tetranychus urticae, but avoided the odour of plants infested with the red mite

503 Oligonychus ilicis. The former is a common, suitable prey for P. macropilis, the latter is

504 not: $O$. ilicis is very rarely found on strawberry and usually does not occur in association

505 with the predator. Doubly infested plants, carrying both herbivores, were not attractive

506 to the predator, which supports the notion that interference in the chemical signalling

507 by the unfamiliar herbivore may occur in this system (Fadini et al., 2010).

508 Specific natural enemies such as the majority of parasitoids are short-lived

509 organisms that often have a limited temporal and developmental window to find their

510 hosts in an excessively complex olfactory landscape. Therefore, it can be expected that

511 they have adapted, not only to the odorous cues betraying the presence of their host, but

512 also to the potential disturbances in HIPVs that may naturally occur in the native

513 environment. These adaptations can take two main forms: 1) A complex array of innate

514 preferences for diverse blends of HIPVs reflecting adaptive choices toward reliable cues

515 (Clavijo McCormick et al., 2012), and 2) plastic preferences relying on associative

516 learning to optimize foraging success (Vet \& Dicke, 1992). Both of these adaptive

517 strategies have been reported in predators (Glinwood, Ahmed, Qvarfordt \& Ninkovic,

518 2011) and parasitoids (Geervliet, Vreugdenhil, Dicke \& Vet, 1998).

This article is protected by copyright. All rights reserved. 
520 novel) and realized impact on native organisms, we can make predictions for insects

521 belonging to the third and fourth trophic levels based on the notions developed through

522 this section. First of all, null plant responses are less likely to have an effect, as plant

523 responses to mechanical damage are usually less intense and less specific compared to

524 plants damaged by herbivores (Dudareva et al., 2006, Wu \& Baldwin, 2010), and

525 therefore likely to be less attractive to natural enemies. On the other hand, similarity in

526 response between plants infested by the exotic and the native herbivore may have

527 critical consequences for natural enemies if the exotic herbivore is a non-host. Indeed

528 identical responses would make plants infested by hosts and non-hosts

529 undistinguishable from a distance, with negative consequences for the foraging

530 efficiency of natural enemies potentially leading to local extinctions due to insufficient

531 parasitism rates (Vos, Berrocal, Karamaouna, Hemerik \& Vet, 2001). Alternatively, if the

532 exotic herbivore can be attacked by natural enemies, then the presence of the exotic

533 herbivore on the plant may not negatively affect natural enemies but may still have

534 consequences for native predator-prey dynamics: on the one hand, native herbivores

535 may partially escape predation/parasitism if the exotic herbivore becomes a favoured

536 prey/host item. On the other hand, natural enemy densities may increase due to the

537 presence of the exotic herbivore as an alternative food, eventually negatively affecting

538 populations of native herbivores. Finally, the impact of novel responses cannot be

539 predicted and will certainly vary greatly among systems. The outcome will depend on

540 the compounds or ratios of compounds that constitute the elements of novelty of the

541 "exotic blend". In such cases of information disruption, the consequences for the natural

542 enemies will strongly depend on their behavioural plasticity and, on the long-term, on

543 their potential for rapid evolutionary adaptations. 
547 Predicting insect-plant interactions in a rapidly changing world is a challenge that

548 conservation ecologists are facing worldwide (Leimu, Muola, Laukkanen, Kalske, Prill \&

549 Mutikainen, 2012, Lürling \& Scheffer, 2007, Pearse et al., 2013, White, Wilson \& Clarke,

550 2006). Thus far, the study of invasive species on community-level interactions has been

551 largely confined to the effects of exotic plants on native plant assemblages (Callaway \&

552 Aschehoug, 2000, Keane \& Crawley, 2002, Sakai, Allendorf, Holt, Lodge, Molofsky, With,

553 Baughman, Cabin, Cohen \& Ellstrand, 2001). The introduction of exotic herbivores or

554 natural enemies can also seriously disrupt the functioning of native communities, with

555 effects rippling through the food chain (Fortuna, Vet \& Harvey, 2012, Kenis et al., 2009,

556 Pearson \& Callaway, 2005). Although these direct and indirect effects of invasive species

557 have been documented, we are not aware of any studies that have specifically addressed

558 the effects of invading insect herbivores on the chemically mediated interactions among

559 plants and native insects. In effect, the presence of an 'interloper' has the potential to

560 diffuse or sever communication channels involving native herbivores, natural enemies,

561 and pollinators, generating spatial asymmetries between different trophic levels that

562 may destabilize tightly linked trophic interactions (Table 1). Moreover, these effects on infochemical networks are likely to depend on the

564 magnitude of the invasion: if the exotic herbivore becomes more abundant than natives,

565 owing to release from its own specialized natural enemies, then it may exert a

566 disproportionate effect on the native community by inflicting more damage on plants

567 than the native herbivores. In this scenario, volatiles released from plants damaged by

568 the invader may dominate the olfactory landscape, amplifying any interference effect 
569 caused by these HIPVs. In closely evolved systems, it can be expected that foraging

570 insects have adapted their responses to plant-emitted signals to optimize resource

571 location, and may thus have evolved some adaptive responses to volatile interferences,

572 but this question has not yet been considered in emerging theory of invasion biology.

573 Regarding the susceptibility of food webs to infochemical disturbances, it is

574 important to keep in mind that, due to domestication, crop plants may have lost some of

575 their ability to emit odorous distress signals in response to herbivory, as has been found

576 for modern varieties of maize that no longer emit root signals that attract

577 entomopathogenic nematodes (Degenhardt, Hiltpold, Köllner, Frey, Gierl, Gershenzon,

578 Hibbard, Ellersieck \& Turlings, 2009, Rasmann, Köllner, Degenhardt, Hiltpold, Toepfer,

579 Kuhlmann, Gershenzon \& Turlings, 2005) or no longer respond to freshly deposited

580 moth eggs that may enhance the plants responses to subsequent caterpillar feeding

581 (Tamiru, Bruce, Woodcock, Caulfield, Midega, Ogol, Mayon, Birkett, Pickett \& Khan,

582 2011). This realization has motivated researchers to restore (Degenhardt et al., 2009),

583 genetically alter (Kappers, Aharoni, Van Herpen, Luckerhoff, Dicke \& Bouwmeester,

584 2005) or artificially enhance (Christensen, Nemchenko, Borrego, Murray, Sobhy, Bosak,

585 DeBlasio, Erb, Robert \& Vaughn, 2013) the volatile emissions in crop plants. Thus,

586 agroecosystems often represent simplified olfactory landscapes compared to natural

587 environments, which may make them even more susceptible to interferences caused by

588 exotic herbivores.

589

Practically, experimental efforts should be made to understand the likelihood and

590 magnitude of disruption of infochemical networks by invasive insect herbivores. In the

591 context of insect invasions, the ecological effects of exotic HIPVs can only be tested by

592 combining careful examination of plant responses to insect invaders at the biochemical

593 level and manipulative experiments with native and exotic insects at the community

This article is protected by copyright. All rights reserved. 
594 level. In the end, measurements of fitness (or fitness correlates) of native insect species

595 in presence and in absence of plant volatiles induced by the invader will be the most

596 valuable indicator of the predicted impact of an invasive species as an "info-disrupter"

597 on a given native environment.

598 Two challenges need to be considered by researchers investigating this topic.

599 Firstly, because the effects of exotic species on the transfer of chemical information are

600 likely to escalate through trophic levels via cascading effects (Harvey et al., 2010), there

601 is a wide variety of interactions involving native organisms that could potentially be

602 impacted by a single invader, making the exhaustive examination of each of them

603 extremely difficult. The challenge lies in determining which interactions should be

604 examined with priority; these decisions should be based on the knowledge of the role

605 and ecological functions of the native species involved in the system studied

606 (Bukovinszky, van Veen, Jongema \& Dicke, 2008). Secondly, measurements of fitness

607 correlates of native organisms under controlled laboratory conditions, despite their

608 usefulness, may have limited value compared to results obtained under field conditions.

609 However, working with exotic species under natural conditions can only be done once

610 the exotic organism has started invading the native environment, diminishing the value

611 of risk assessments and impact predictions. To overcome this obstacle, researchers may

612 take advantage of newly invaded environments to conduct field research in a still

613 "naïve" ecosystem, and extrapolate results to areas at risk of being invaded in the future.

614 This approach may be particularly valuable in the case of range-expanding species,

615 owing to global changes such as global warming (Sorte, Williams \& Zerebecki, 2010,

616 Walther, Roques, Hulme, Sykes, Pyšek, Kühn, Zobel, Bacher, Botta-Dukát \& Bugmann,

617 2009).

618 Acknowledgements

This article is protected by copyright. All rights reserved. 
619 The main authors are grateful to the Swiss National Science Foundation, which finances

620 their contribution in the context of the EUROCORES Programme EuroVOL (project

621 InvaVOL) of the European Science Foundation. Thomas Degen (www.thomas-degen.ch)

622 provided Figure 1.

623

624 References

625 Adler L.S., Karban R. \& Strauss S.Y. (2001) Direct and indirect effects of alkaloids on

626 plant fitness via herbivory and pollination. Ecology, 82, 2032-2044.

627 Agrawal A.A. (2000) Specificity of induced resistance in wild radish: causes and

628 consequences for two specialist and two generalist caterpillars. Oikos, 89, 493-

629500.

630 Akhtar Y. \& Isman M. (2003) Larval exposure to oviposition deterrents alters subsequent oviposition behavior in generalist, Trichoplusia ni and Specialist,

632 Plutella xylostella Moths. Journal of Chemical Ecology, 29, 1853-1870.

633 Allison J.D. \& Hare D.J. (2009) Learned and naive natural enemy responses and the interpretation of volatile organic compounds as cues or signals. New Phytologist, 184, 768-782.

636 Arimura G.-i., Köpke S., Kunert M., Volpe V., David A., Brand P., Dabrowska P., Maffei M.E. 637 \& Boland W. (2008) Effects of feeding Spodoptera littoralis on lima bean leaves: IV. Diurnal and nocturnal damage differentially initiate plant volatile emission.

640 Arimura G.-i., Matsui K. \& Takabayashi J. (2009) Chemical and molecular ecology of 641 herbivore-induced plant volatiles: proximate factors and their ultimate functions. $642 \quad$ Plant and Cell Physiology, 50, 911-923. 
643 Arimura G.-i., Ozawa R., Horiuchi J.-i., Nishioka T. \& Takabayashi J. (2001) Plant-plant 644 interactions mediated by volatiles emitted from plants infested by spider mites. $645 \quad$ Biochemical Systematics and Ecology, 29, 1049-1061.

646 Balbyshev N.F. \& Lorenzen J.H. (1997) Hypersensitivity and egg drop: a novel

647 mechanism of host plant resistance to Colorado potato beetle (Coleoptera:

648 Chrysomelidae). Journal of Economic Entomology, 90, 652-657.

649 Bartkowska M.P. \& Johnston M.O. (2012) Pollinators cause stronger selection than 650 herbivores on floral traits in Lobelia cardinalis (Lobeliaceae). New Phytologist, $651 \quad 193,1039-1048$.

652 Becerra J.X. (1997) Insects on plants: macroevolutionary chemical trends in host use.

653 Science, 276, 253-256.

654 Behmer S.T. (2008) Insect herbivore nutrient regulation. Annual Review of Entomology, $655 \quad 54,165$.

656 Behmer S.T. \& Elias D.O. (2000) Sterol metabolic constraints as a factor contributing to 657 the maintenance of diet mixing in grasshoppers (Orthoptera: Acrididae).

658 Physiological and Biochemical Zoology, 73, 219-230.

659 Bernays E.A. \& Chapman R.F. (1994) Host-plant selection by phytophagous insects.

$660 \quad$ Springer.

661 Bidart-Bouzat M.G. \& Kliebenstein D. (2011) An ecological genomic approach

662 challenging the paradigm of differential plant responses to specialist versus

663 generalist insect herbivores. Oecologia, 167, 677-689.

664 Blight M., Pickett J., Wadhams L. \& Woodcock C. (1995) Antennal perception of oilseed 665 rape, Brassica napus (Brassicaceae), volatiles by the cabbage seed weevil 666 Ceutorhynchus assimilis (Coleoptera, Curculionidae). Journal of Chemical Ecology, $667 \quad 21,1649-1664$. 
668 Bruce T.J., Wadhams L.J. \& Woodcock C.M. (2005) Insect host location: a volatile 669 situation. Trends in Plant Science, 10, 269-274.

670 Bukovinszky T., Poelman E.H., Kamp A., Hemerik L., Prekatsakis G. \& Dicke M. (2012) Plants under multiple herbivory: consequences for parasitoid search behaviour and foraging efficiency. Animal Behaviour, 83, 501-509.

673 Bukovinszky T., van Veen F.F., Jongema Y. \& Dicke M. (2008) Direct and indirect effects 674 of resource quality on food web structure. Science, 319, 804-807.

675 Callaway R.M. \& Aschehoug E.T. (2000) Invasive plants versus their new and old 676 neighbors: a mechanism for exotic invasion. Science, 290, 521-523.

677 Cardel Y.J. \& Koptur S. (2010) Effects of florivory on the pollination of flowers: an 678 experimental field study with a perennial plant. International Journal of Plant $679 \quad$ Sciences, 171, 283-292.

680 Chen Y., Schmelz E.A., Wäckers F. \& Ruberson J.R. (2008) Cotton plant, Gossypium 681 hirsutum L., defense in response to nitrogen fertilization. Journal of Chemical 682 Ecology, 34, 1553-1564.

683 Christensen S.A., Nemchenko A., Borrego E., Murray I., Sobhy I.S., Bosak L., DeBlasio S., 684 Erb M., Robert C.A. \& Vaughn K.A. (2013) The maize lipoxygenase, ZmLOX10, mediates green leaf volatile, jasmonate and herbivore-induced plant volatile production for defense against insect attack. The Plant Journal.

687 Clavijo McCormick A., Unsicker S.B. \& Gershenzon J. (2012) The specificity of herbivore688 induced plant volatiles in attracting herbivore enemies. Trends in Plant Science, 689 17, 303-310.

690 Colazza S., Cusumano A., Giudice D.L. \& Peri E. (2014) Chemo-orientation responses in 691 hymenopteran parasitoids induced by substrate-borne semiochemicals. BioControl, 59, 1-17. 
693 Connor E.C., Rott A.S., Samietz J. \& Dorn S. (2007) The role of the plant in attracting parasitoids: response to progressive mechanical wounding. Entomologia Experimentalis et Applicata, 125, 145-155.

696 Cunningham J.P., Moore C.J., Zalucki M.P. \& West S.A. (2004) Learning, odour preference 697 and flower foraging in moths. Journal of Experimental Biology, 207, 87-94.

698 Danderson C.A. \& Molano-Flores B. (2010) Effects of herbivory and inflorescence size on 699 insect visitation to Eryngium yuccifolium (Apiaceae) a prairie plant. The American 700 Midland Naturalist, 163, 234-246.

701 De Moraes C.M., Mescher M.C. \& Tumlinson J.H. (2001) Caterpillar-induced nocturnal 702 plant volatiles repel conspecific females. Nature, 410, 577-580.

703 de Rijk M., Dicke M. \& Poelman E.H. (2013) Foraging behaviour by parasitoids in $704 \quad$ multiherbivore communities. Animal Behaviour, 85, 1517-1528.

705 Degenhardt J., Hiltpold I., Köllner T.G., Frey M., Gierl A., Gershenzon J., Hibbard B.E., 706 Ellersieck M.R. \& Turlings T.C. (2009) Restoring a maize root signal that attracts 707 insect-killing nematodes to control a major pest. Proceedings of the National $708 \quad$ Academy of Sciences, 106, 13213-13218.

709 Desurmont G.A., Donoghue M.J., Clement W.L. \& Agrawal A.A. (2011) Evolutionary 710 history predicts plant defense against an invasive pest. Proceedings of the 711 National Academy of Sciences, 108, 7070-7074.

712 Desurmont G.A. \& Weston P.A. (2010) Stimuli associated with viburnum leaf beetle 713 (Pyrrhalta viburni) aggregative oviposition behavior. Entomologia Experimentalis et Applicata, 135, 245-251.

715 Desurmont G.A. \& Weston P.A. (2011) Aggregative oviposition of a phytophagous beetle 716 overcomes egg-crushing plant defences. Ecological Entomology, 36, 335-343. 
717 Dicke M. (1999) Are herbivore-induced plant volatiles reliable indicators of herbivore identity to foraging carnivorous arthropods? In: Proceedings of the 10th International Symposium on Insect-Plant Relationships (eds S. Simpson, A.J. Mordue, \& J. Hardie), pp. 131-142. Springer Netherlands.

721 Dicke M. \& Sabelis M.W. (1988) How Plants Obtain Predatory Mites as Bodyguards. 722 Netherlands Journal of Zoology, 38, 148-165.

723 Dudareva N., Negre F., Nagegowda D.A. \& Orlova I. (2006) Plant volatiles: recent advances and future perspectives. Critical Reviews in Plant Sciences, 25, 417-440.

725 Eigenbrode S.D., Ding H., Shiel P. \& Berger P.H. (2002) Volatiles from potato plants

726 infected with potato leafroll virus attract and arrest the virus vector, Myzus persicae (Homoptera: Aphididae). Proceedings of the Royal Society of London.

$728 \quad$ Series B: Biological Sciences, 269, 455-460.

729 Fadini M.A., Venzon M., Oliveira H., Pallini A. \& Vilela E.F. (2010) Response of the 730 predatory mite Phytoseiulus macropilis (Banks) to volatiles produced by 731 strawberry plants in response to attack by Tetranychid mites (Acari:

732 Phytoseiidae: Tetranychidae). Neotropical Entomology, 39, 248-252.

733 Fatouros N.E., Bukovinszkine'Kiss G., Dicke M. \& Hilker M. (2007) The response $734 \quad$ specificity of Trichogramma egg parasitoids towards infochemicals during host 735 location. Journal of Insect Behavior, 20, 53-65.

736 Fenster C.B., Armbruster W.S., Wilson P., Dudash M.R. \& Thomson J.D. (2004) Pollination syndromes and floral specialization. Annual Review of Ecology, Evolution, and Systematics, 375-403.

739 Fitt G.P. (1989) The ecology of Heliothis species in relation to agroecosystems. Annual Review of Entomology, 34, 17-53. 
741 Fordyce J. (2003) Aggregative feeding of pipevine swallowtail larvae enhances hostplant suitability. Oecologia, 135, 250-257.

743 Fortuna T.M., Vet L.E. \& Harvey J.A. (2012) Effects of an invasive plant on the performance of two parasitoids with different host exploitation strategies. Biological Control, 62, 213-220.

746 Gandhi K.J. \& Herms D.A. (2010) Direct and indirect effects of alien insect herbivores on 747 ecological processes and interactions in forests of eastern North America. Biological Invasions, 12, 389-405.

749 Geervliet J.B., Vreugdenhil A.I., Dicke M. \& Vet L.E. (1998) Learning to discriminate 750 between infochemicals from different plant-host complexes by the parasitoids Cotesia glomerata and C. rubecula. Entomologia Experimentalis et Applicata, 86, 241-252.

753 Gilbert G.S., Magarey R., Suiter K. \& Webb C.0. (2012) Evolutionary tools for phytosanitary risk analysis: phylogenetic signal as a predictor of host range of plant pests and pathogens. Evolutionary Applications, 5, 869-878.

756 Girling R.D., Stewart-Jones A., Dherbecourt J., Staley J.T., Wright D.J. \& Poppy G.M. (2011) Parasitoids select plants more heavily infested with their caterpillar hosts: a new approach to aid interpretation of plant headspace volatiles. Proceedings of the Royal Society B: Biological Sciences, 278, 2646-2653.

760 Glinwood R., Ahmed E., Qvarfordt E. \& Ninkovic V. (2011) Olfactory learning of plant genotypes by a polyphagous insect predator. Oecologia, 166, 637-647.

762 Godfray H.C.J. (1994) Parasitoids: behavioral and evolutionary ecology. Princeton University Press.

764 Gouinguené S.P. \& Turlings T.C. (2002) The effects of abiotic factors on induced volatile emissions in corn plants. Plant Physiology, 129, 1296-1307. 

damage leaf surfaces and initiate rapid responses. European Journal of Plant Pathology, 110, 441-447.

769 Hare J.D. (2011) Ecological role of volatiles produced by plants in response to damage by herbivorous insects. Annual Review of Entomology, 56, 161-180.

771 Harvey J.A., Bukovinszky T. \& van der Putten W.H. (2010) Interactions between invasive 772 plants and insect herbivores: A plea for a multitrophic perspective. Biological Conservation, 143, 2251-2259.

774 Harvey J.A. \& Fortuna T.M. (2012) Chemical and structural effects of invasive plants on 775 herbivore-parasitoid/predator interactions in native communities. Entomologia Experimentalis et Applicata, 144, 14-26.

777 Hassell M. \& May R. (1986) Generalist and specialist natural enemies in insect predator778 prey interactions. The Journal of Animal Ecology, 923-940.

779 Heil M. (2004) Direct defense or ecological costs: responses of herbivorous beetles to 780 volatiles released by wild lima bean (Phaseolus lunatus). Journal of Chemical 781 Ecology, 30, 1289-1295.

782 Heil M. \& Karban R. (2010) Explaining evolution of plant communication by airborne 783 signals. Trends in Ecology \& Evolution, 25, 137-144.

784 Hilker M. \& Meiners T. (2010) How do plants "notice" attack by herbivorous arthropods? Biological Reviews, 85, 267-280.

786 Holopainen J.K. (2004) Multiple functions of inducible plant volatiles. Trends in Plant 787 Science, 9, 529-533.

788 Horiuchi J.-I., Arimura G.-I., Ozawa R., Shimoda T., Dicke M., Takabayashi J. \& Nishioka T. 789 (2003) Lima bean leaves exposed to herbivore-induced conspecific plant 
volatiles attract herbivores in addition to carnivores. Applied Entomology and Zoology, 38, 365-368.

792 Horiuchi J.-I., Arimura G.-I., Ozawa R., Shimoda T., Takabayashi J. \& Nishioka T. (2003) A comparison of the responses of Tetranychus urticae (Acari: Tetranychidae) and

794 Phytoseiulus persimilis (Acari: Phytoseiidae) to volatiles emitted from lima bean

795

796 leaves with different levels of damage made by T. urticae or Spodoptera exigua (Lepidoptera: Noctuidae). Applied Entomology and Zoology, 38, 109-116.

797 Johnson S.N. \& Nielsen U.N. (2012) Foraging in the dark-chemically mediated host plant 798 location by belowground insect herbivores. Journal of Chemical Ecology, 38, 604799 614.

800 Kappers I.F., Aharoni A., Van Herpen T.W., Luckerhoff L.L., Dicke M. \& Bouwmeester H.J. 801 (2005) Genetic engineering of terpenoid metabolism attracts bodyguards to 802 Arabidopsis. Science Signaling, 309, 2070.

803 Karban R. (2001) Communication between sagebrush and wild tobacco in the field. $804 \quad$ Biochemical Systematics and Ecology, 29, 995-1005.

805 Karban R., Agrawal A.A. \& Mangel M. (1997) The benefits of induced defenses against 806 herbivores. Ecology, 78, 1351-1355.

807 Keane R.M. \& Crawley M.J. (2002) Exotic plant invasions and the enemy release 808 hypothesis. Trends in Ecology \& Evolution, 17, 164-170.

809 Keeler M.S. \& Chew F.S. (2008) Escaping an evolutionary trap: preference and 810 performance of a native insect on an exotic invasive host. Oecologia, 156, 559568.

812 Kenis M., Auger-Rozenberg M.-A., Roques A., Timms L., Péré C., Cock M.J., Settele J., Augustin S. \& Lopez-Vaamonde C. (2009) Ecological effects of invasive alien 
816 Kessler A. \& Baldwin I.T. (2001) Defensive function of herbivore-induced plant volatile emissions in nature. Science, 291, 2141-2144.

818 Kessler A. \& Halitschke R. (2007) Specificity and complexity: the impact of herbivore-

819 induced plant responses on arthropod community structure. Current Opinion in 820 Plant Biology, 10, 409-414.

821 Kessler A. \& Halitschke R. (2009) Testing the potential for conflicting selection on floral chemical traits by pollinators and herbivores: predictions and case study. Functional Ecology, 23, 901-912.

824 Kessler A., Halitschke R. \& Poveda K. (2011) Herbivory-mediated pollinator limitation:

825 Negative impacts of induced volatiles on plant-pollinator interactions. Ecology, 92, 1769-1780.

827 Kessler D., Diezel C. \& Baldwin I.T. (2010) Changing pollinators as a means of escaping 828 herbivores. Current Biology, 20, 237-242.

829 Lehtilä K. \& Strauss S.Y. (1997) Leaf damage by herbivores affects attractiveness to pollinators in wild radish, Raphanus raphanistrum. Oecologia, 111, 396-403.

831 Leimu R., Muola A., Laukkanen L., Kalske A., Prill N. \& Mutikainen P. (2012) Plant-herbivore coevolution in a changing world. Entomologia Experimentalis et Applicata, 144, 3-13.

834 Lohman D., Zangerl A. \& Berenbaum M. (1996) Impact of floral herbivory by parsnip webworm (Oecophoridae: Depressaria pastinacella Duponchel) on pollination and fitness of wild parsnip (Apiaceae: Pastinaca sativa L.). American Midland Naturalist, 407-412. 
838 Lucas-Barbosa D., van Loon J.J.A. \& Dicke M. (2011) The effects of herbivore-induced plant volatiles on interactions between plants and flower-visiting insects. Phytochemistry, 72, 1647-1654.

841 Lürling M. \& Scheffer M. (2007) Info-disruption: pollution and the transfer of chemical information between organisms. Trends in Ecology \& Evolution, 22, 374-379.

843 McCall A.C. \& Irwin R.E. (2006) Florivory: the intersection of pollination and herbivory. 844 Ecology Letters, 9, 1351-1365.

845 Meiners T., Hacker N., Anderson P. \& Hilker M. (2005) Response of the elm leaf beetle to 846 host plants induced by oviposition and feeding: the infestation rate matters. Entomologia Experimentalis et Applicata, 115, 171-177.

848 Mithöfer A. \& Boland W. (2008) Recognition of herbivory-associated molecular patterns. Plant Physiology, 146, 825-831.

850 Mithöfer A. \& Boland W. (2012) Plant defense against herbivores: chemical aspects. Annual Review of Plant Biology, 63, 431-450.

852 Mithöfer A., Wanner G. \& Boland W. (2005) Effects of feeding Spodoptera littoralis on

853 lima bean leaves. II. Continuous mechanical wounding resembling insect feeding 854 is sufficient to elicit herbivory-related volatile emission. Plant Physiology, 137, $1160-1168$.

856 Mori N. \& Yoshinaga N. (2011) Function and evolutionary diversity of fatty acid amino 857 acid conjugates in insects. Journal of Plant Interactions, 6, 103-107.

858 Mumm R. \& Dicke M. (2010) Variation in natural plant products and the attraction of 859 bodyguards involved in indirect plant defense. Canadian Journal of Zoology, 88,

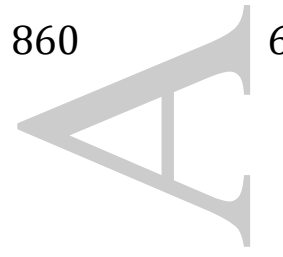
628-667. 
861 Nottingham S.F., Hardie J., Dawson G.W., Hick A.J., Pickett J.A., Wadhams L.J. \& Woodcock C.M. (1991) Behavioral and electrophysiological responses of aphids to host and nonhost plant volatiles. Journal of Chemical Ecology, 17, 1231-1242.

864 Pare P.W., Farag M.A., Krishnamachari V., Zhang H., Ryu C.-M. \& Kloepper J.W. (2005)

865 Elicitors and priming agents initiate plant defense responses. Photosynthesis

866 Research, 85, 149-159.

867 Pearse I.S., Harris D.J., Karban R. \& Sih A. (2013) Predicting novel herbivore-plant $868 \quad$ interactions. Oikos, 122, 1554-1564.

869 Pearson D.E. \& Callaway R.M. (2005) Indirect nontarget effects of host-specific biological 870 control agents: Implications for biological control. Biological Control, 35, 288871298.

872 Peñuelas J. \& Llusià J. (2004) Plant VOC emissions: making use of the unavoidable. Trends in Ecology \& Evolution, 19, 402-404.

874 Pichersky E. \& Gershenzon J. (2002) The formation and function of plant volatiles:

875 perfumes for pollinator attraction and defense. Current Opinion in Plant Biology, $876 \quad \mathbf{5}, 237-243$.

877 Pierre P.S., Jansen J.J., Hordijk C.A., van Dam N.M., Cortesero A.-M. \& Dugravot S. (2011) 878 Differences in volatile profiles of turnip plants subjected to single and dual 879 herbivory above-and belowground. Journal of Chemical Ecology, 37, 368-377.

880 Poelman E.H., Broekgaarden C., Van Loon J.J.A. \& Dicke M. (2008) Early season herbivore 881 differentially affects plant defence responses to subsequently colonizing 882 herbivores and their abundance in the field. Molecular Ecology, 17, 3352-3365.

883 Poelman E.H., Bruinsma M., Zhu F., Weldegergis B.T., Boursault A.E., Jongema Y., van 884 Loon J.J., Vet L.E., Harvey J.A. \& Dicke M. (2012) Hyperparasitoids use herbivore- 
induced plant volatiles to locate their parasitoid host. PLoS Biology, 10, e1001435.

887 Poelman E.H., Zheng S.-J., Zhang Z., Heemskerk N.M., Cortesero A.-M. \& Dicke M. (2011) Parasitoid-specific induction of plant responses to parasitized herbivores affects

889 colonization by subsequent herbivores. Proceedings of the National Academy of

890 Sciences, 108, 19647-19652.

891 Poveda K., Steffan-Dewenter I., Scheu S. \& Tscharntke T. (2003) Effects of below-and above-ground herbivores on plant growth, flower visitation and seed set.

893 Oecologia, 135, 601-605.

894 Quicke D.L. (1997) Parasitic wasps. Chapman \& Hall Ltd.

895 Radville L., Chaves A. \& Preisser E.L. (2011) Variation in plant defense against invasive 896 herbivores: evidence for a hypersensitive response in eastern hemlocks (Tsuga canadensis). Journal of Chemical Ecology, 37, 592-597.

898 Raffa K.F., Phillips T.W. \& Salom S.M. (1993) Strategies and mechanisms of host

899 colonization by bark beetles. In: Beetle-pathogen interactions in conifer forests

900 (eds T.O. Schowalter \& G. Filip), pp. 103-128. Academic Press, New York.

901 Raguso R.A. (2008) Wake up and smell the roses: the ecology and evolution of floral 902 scent. Annual Review of Ecology, Evolution, and Systematics, 39, 549-569.

903 Rasmann S., Köllner T.G., Degenhardt J., Hiltpold I., Toepfer S., Kuhlmann U., Gershenzon 904 J. \& Turlings T.C. (2005) Recruitment of entomopathogenic nematodes by insect905 damaged maize roots. Nature, 434, 732-737.

906 Reaser J.K., Meyerson L.A., Cronk Q., De Poorter M., Eldrege L., Green E., Kairo M., Latasi 907 P., Mack R.N. \& Mauremootoo J. (2007) Ecological and socioeconomic impacts of 908 invasive alien species in island ecosystems. Environmental Conservation, 34, 98111. 
910 Reymond P. (2013) Perception, signaling and molecular basis of oviposition-mediated plant responses. Planta, 238, 247-258.

912 Riffell J.A. (2011) The neuroecology of a pollinator's buffet: olfactory preferences and learning in insect pollinators. Integrative and Comparative Biology, 51, 781-793.

914 Robert C.A.M., Erb M., Hibbard B.E., French B.W., Zwahlen C. \& Turlings T.C.J. (2012) A

915 specialist root herbivore reduces plant resistance and uses an induced plant

916 volatile to aggregate in a density-dependent manner. Functional Ecology, 26, $917 \quad 1429-1440$.

918 Sakai A.K., Allendorf F.W., Holt J.S., Lodge D.M., Molofsky J., With K.A., Baughman S., Cabin 919 R.J., Cohen J.E. \& Ellstrand N.C. (2001) The population biology of invasive species. $920 \quad$ Annual Review of Ecology and Systematics, 305-332.

921 Schiestl F.P. (2010) The evolution of floral scent and insect chemical communication. Ecology Letters, 13, 643-656.

923 Schiestl F.P. \& Johnson S.D. (2013) Pollinator-mediated evolution of floral signals. Trends 924 in Ecology \& Evolution.

925 Shiojiri K., Takabayashi J., Yano S. \& Takafuji A. (2002) Oviposition preferences of 926 herbivores are affected by tritrophic interaction webs. Ecology Letters, 5, 186192.

928 Smallegange R., Van Loon J., Blatt S., Harvey J., Agerbirk N. \& Dicke M. (2007) Flower vs. 929 leaf feeding by Pieris brassicae: glucosinolate-rich flower tissues are preferred 930 and sustain higher growth rate. Journal of Chemical Ecology, 33, 1831-1844. 931 Snoeren T.A., Mumm R., Poelman E.H., Yang Y., Pichersky E. \& Dicke M. (2010) The 932 herbivore-induced plant volatile methyl salicylate negatively affects attraction of 933 the parasitoid Diadegma semiclausum. Journal of Chemical Ecology, 36, 479-489. 
934 Sorte C.J., Williams S.L. \& Zerebecki R.A. (2010) Ocean warming increases threat of invasive species in a marine fouling community. Ecology, 91, 2198-2204.

936 Tamiru A., Bruce T.J., Woodcock C.M., Caulfield J.C., Midega C.A., Ogol C.K., Mayon P., 937 Birkett M.A., Pickett J.A. \& Khan Z.R. (2011) Maize landraces recruit egg and 938 larval parasitoids in response to egg deposition by a herbivore. Ecology Letters,

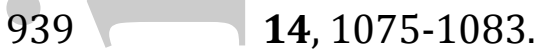

940 Ton J., D'Alessandro M., Jourdie V., Jakab G., Karlen D., Held M., Mauch-Mani B. \& Turlings 941 T.C. (2007) Priming by airborne signals boosts direct and indirect resistance in maize. The Plant Journal, 49, 16-26.

943 Tumlinson J.H. \& Engelberth J. (2008) Fatty acid-derived signals that induce or regulate plant defenses against herbivory. In: Induced Plant Resistance to Herbivory, pp.

945 389-407. Springer.

946 Turlings T.C., Tumlinson J.H. \& Lewis W. (1990) Exploitation of herbivore-induced plant odors by host-seeking parasitic wasps. Science, 250, 1251-1253.

948 Turlings T.C., Wäckers F.L., Vet L.E., Lewis W.J. \& Tumlinson J.H. (1993) Learning of host-

949 finding cues by hymenopterous parasitoids. In: Insect learning, pp. 51-78.

950 Springer.

951 Vet L.E. \& Dicke M. (1992) Ecology of infochemical use by natural enemies in a tritrophic 952 context. Annual Review of Entomology, 37, 141-172.

953 Vet L.E., Lewis W.J. \& Carde R.T. (1995) Parasitoid foraging and learning. In: Chemical 954 Ecology of Insects 2 (eds R.T. Cardé \& W.J. Bell), pp. 65-101. Springer.

955 Vilà M., Espinar J.L., Hejda M., Hulme P.E., Jarošík V., Maron J.L., Pergl J., Schaffner U., Sun 956 Y. \& Pyšek P. (2011) Ecological impacts of invasive alien plants: a meta-analysis 957 of their effects on species, communities and ecosystems. Ecology Letters, 14, 702708. 

Applicata, 24, 738-749.

962 Vos M., Berrocal S.M., Karamaouna F., Hemerik L. \& Vet L. (2001) Plant-mediated

963 indirect effects and the persistence of parasitoid-herbivore communities. Ecology

964 Letters, 4, 38-45.

965 Walther G.-R., Roques A., Hulme P.E., Sykes M.T., Pyšek P., Kühn I., Zobel M., Bacher S., 966 Botta-Dukát Z. \& Bugmann H. (2009) Alien species in a warmer world: risks and opportunities. Trends in Ecology \& Evolution, 24, 686-693.

968 Webster B., Qvarfordt E., Olsson U. \& Glinwood R. (2013) Different roles for innate and learnt behavioral responses to odors in insect host location. Behavioral Ecology, 24, 366-372.

971 White E.M., Wilson J.C. \& Clarke A.R. (2006) Biotic indirect effects: a neglected concept in invasion biology. Diversity and Distributions, 12, 443-455.

973 Winter T.R. \& Rostás M. (2010) Nitrogen deficiency affects bottom-up cascade without 974 disrupting indirect plant defense. Journal of Chemical Ecology, 36, 642-651.

975 Woodard A.M., Ervin G.N. \& Marsico T.D. (2012) Host plant defense signaling in response

976 to a coevolved herbivore combats introduced herbivore attack. Ecology and 977 Evolution, 2, 1056-1064.

978 Wright G.A. \& Schiestl F.P. (2009) The evolution of floral scent: the influence of olfactory 979 learning by insect pollinators on the honest signalling of floral rewards. 980 Functional Ecology, 23, 841-851.

981 Wu J. \& Baldwin I.T. (2010) New insights into plant responses to the attack from insect herbivores. Annual Review of Genetics, 44, 1-24. 
983 Yoneya K., Kugimiya S. \& Takabayashi J. (2009) Can herbivore-induced plant volatiles 984 inform predatory insect about the most suitable stage of its prey? Physiological 985 Entomology, 34, 379-386.

986 Yoshinaga N., Alborn H.T., Nakanishi T., Suckling D.M., Nishida R., Tumlinson J.H. \& Mori 987 N. (2010) Fatty acid-amino acid conjugates diversification in lepidopteran 988 caterpillars. Journal of Chemical Ecology, 36, 319-325.

989

990

991

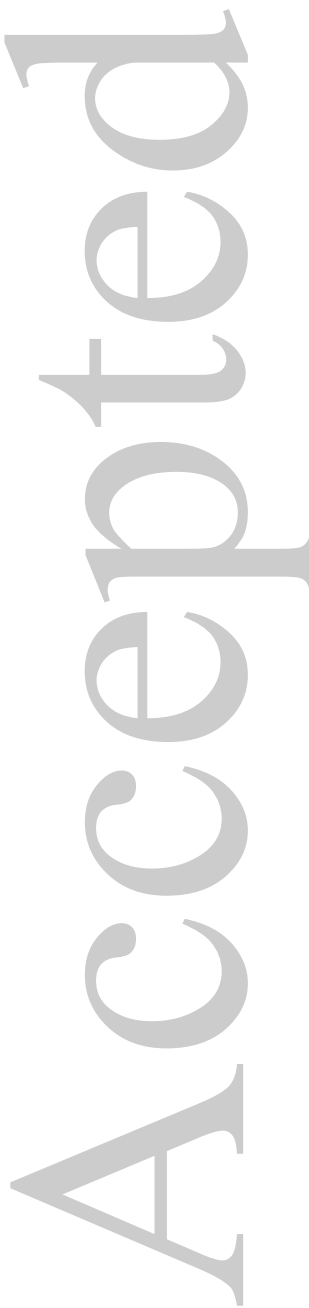


994 Table 1. Examples of interferences in infochemical networks.

\begin{tabular}{|c|c|c|c|c|}
\hline $\begin{array}{c}\text { Type of } \\
\text { interaction }\end{array}$ & $\begin{array}{l}\text { Organisms } \\
\text { involved }\end{array}$ & $\begin{array}{l}\text { Origin of the } \\
\text { interference }\end{array}$ & Result of the interference & Reference \\
\hline $\begin{array}{l}\text { Herbivore- } \\
\text { herbivore and } \\
\text { Predator-prey }\end{array}$ & $\begin{array}{l}\text { Parasitic wasp- } \\
\text { caterpillars }\end{array}$ & $\begin{array}{l}\text { Native } \\
\text { herbivore } \\
\text { species }\end{array}$ & $\begin{array}{l}\text { Presence of a non-host } \\
\text { herbivore decreases the } \\
\text { attractiveness of host-infested } \\
\text { plants for the parasitic wasp. } \\
\text { Host herbivores favour plant } \\
\text { infested by the non host for } \\
\text { oviposition. }\end{array}$ & $\begin{array}{l}\text { Shiojiri et al. } \\
2002\end{array}$ \\
\hline Predator-prey & $\begin{array}{l}\text { Zooplancton - } \\
\text { alga }\end{array}$ & Pollutant & $\begin{array}{c}\text { Presence of a surfactant } \\
\text { induces a costly anti-predator } \\
\text { aggregation behaviour in a } \\
\text { green alga }\end{array}$ & Lürling 2007 \\
\hline tor-prey & $\begin{array}{l}\text { Predatory mite - } \\
\text { Spider mites }\end{array}$ & $\begin{array}{l}\text { Uncommon } \\
\text { herbivore } \\
\text { species }\end{array}$ & $\begin{array}{l}\text { Presence of the uncommon } \\
\text { herbivore decreases the } \\
\text { attractiveness of plants } \\
\text { damaged by suitable prey }\end{array}$ & $\begin{array}{l}\text { Fadini et al. } \\
\quad 2010\end{array}$ \\
\hline Predator-prey & $\begin{array}{l}\text { Parasitic wasp- } \\
\text { caterpillar }\end{array}$ & $\begin{array}{l}\text { Native } \\
\text { herbivore } \\
\text { species }\end{array}$ & $\begin{array}{l}\text { Presence of a non-host } \\
\text { herbivore increases the } \\
\text { attractiveness of host-infested } \\
\text { plants, but decreases the } \\
\text { searching efficiency of the } \\
\text { parasitoid. }\end{array}$ & $\begin{array}{l}\text { Bukovinszky et } \\
\text { al. } 2012\end{array}$ \\
\hline $\begin{array}{l}\text { Pollinator- } \\
\text { flower }\end{array}$ & $\begin{array}{l}\text { Wild tomato } \\
\text { plants-bees }\end{array}$ & $\begin{array}{l}\text { Native } \\
\text { herbivore } \\
\text { species }\end{array}$ & $\begin{array}{c}\text { Plants damaged by herbivores } \\
\text { show reduced attractiveness } \\
\text { to pollinators and suffer } \\
\text { reduced seed sets. }\end{array}$ & $\begin{array}{l}\text { Kessler et al. } \\
2011\end{array}$ \\
\hline $\begin{array}{c}\text { Pollinator- } \\
\text { flower }\end{array}$ & $\begin{array}{l}\text { Wild radish- } \\
\text { syrphid flies }\end{array}$ & $\begin{array}{l}\text { Native } \\
\text { herbivore } \\
\text { species }\end{array}$ & $\begin{array}{l}\text { Lower pollinator visitation } \\
\text { rates on plants damaged by } \\
\text { herbivores }\end{array}$ & $\begin{array}{l}\text { Lehtilä and } \\
\text { Strauss } 1997\end{array}$ \\
\hline
\end{tabular}


999 Figure legends

1000 Figure 1. Illustration of how invasive insect herbivore may disrupt infochemical 1001 networks through interferences in herbivore induced plant volatiles (illustration by 1002 Thomas Degen).

1003 Figure 2. Illustration of conceivable plant responses to exotic herbivory. Letters 1004 represent volatile compounds emitted in response to mechanical damage or to feeding 1005 by two native herbivores. Three types of plant response to exotic herbivory are 1006 proposed. Null response: the blend emitted resembles the blend emitted after 1007 mechanical damage. Identical response: the blend emitted resembles the blend emitted 1008 in response to one native species (here, herbivore \#1). Novel response: the blend 1009 emitted diverges from the blend emitted in response to native herbivores. 

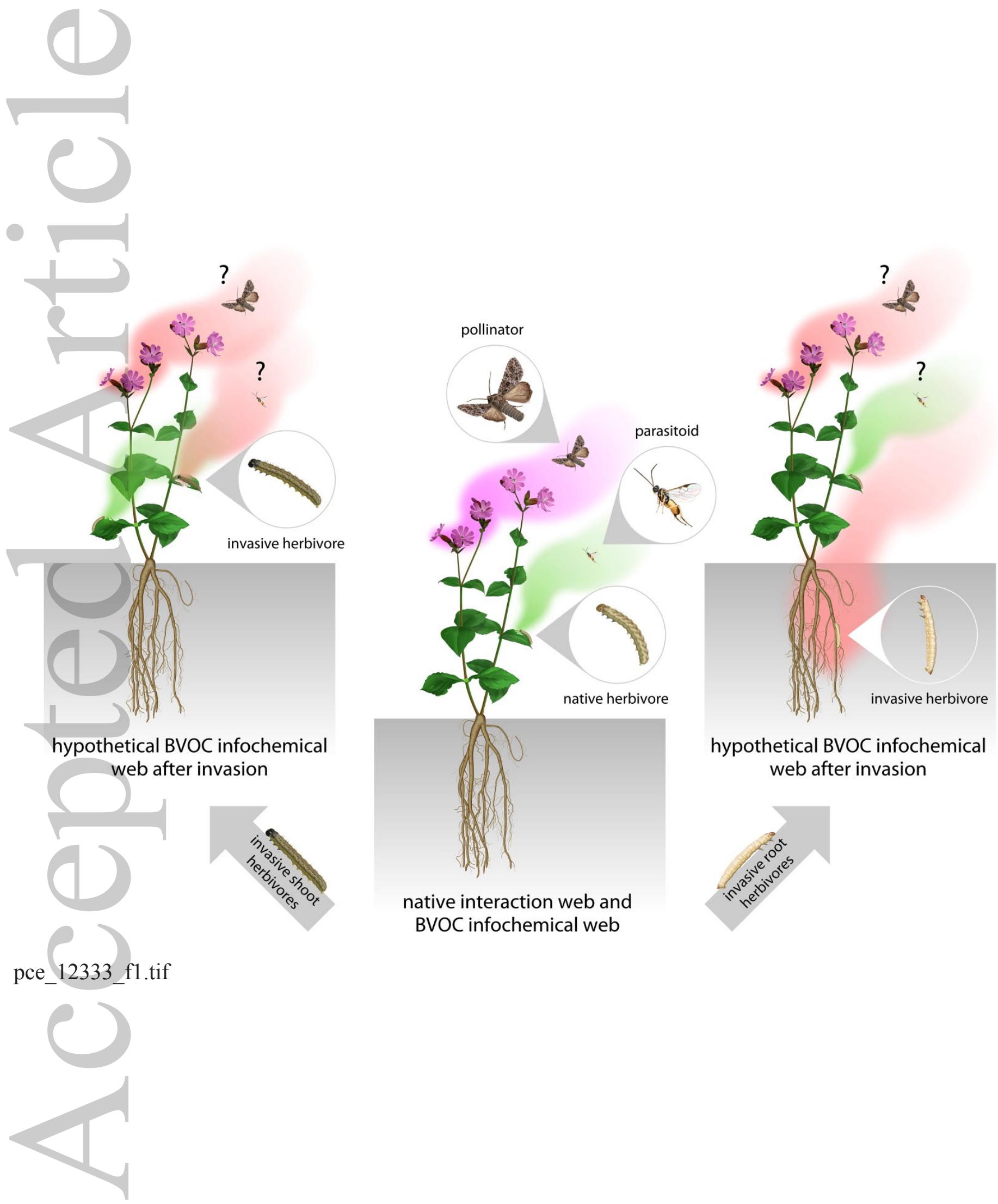


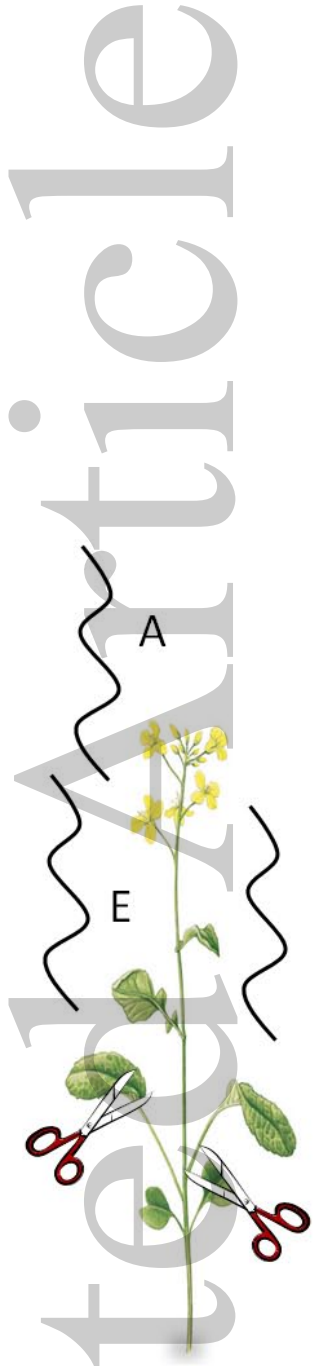

Mechanical damage

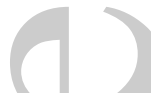

pce_12333_f2.tif

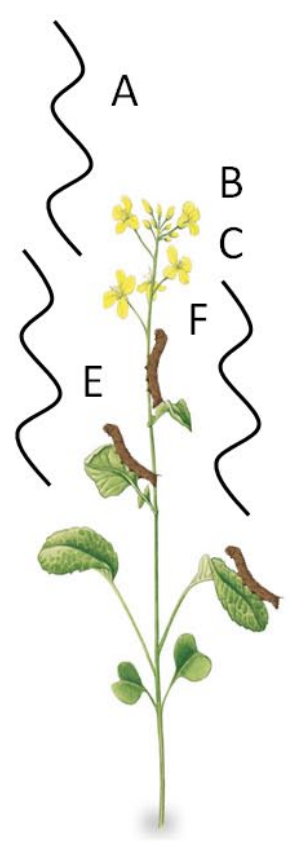

Native herbivore \#1 herbivore \#2

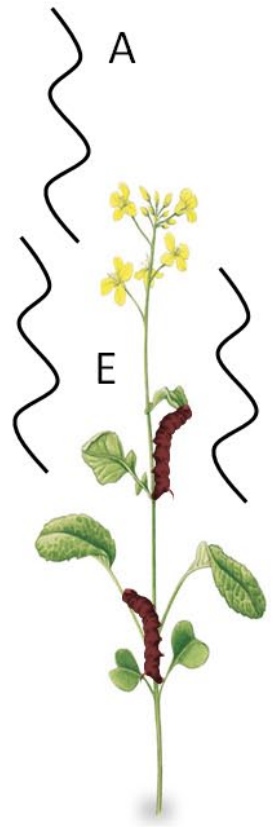

Null response

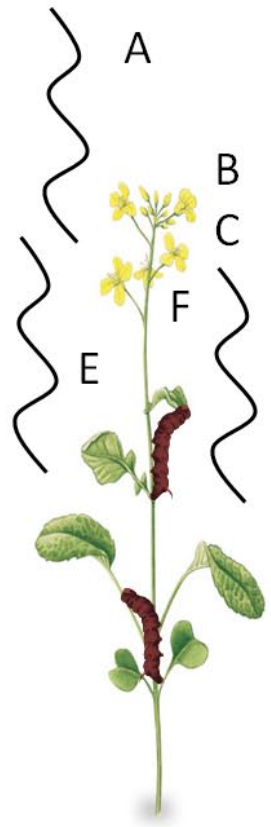

Similar response $\int A$

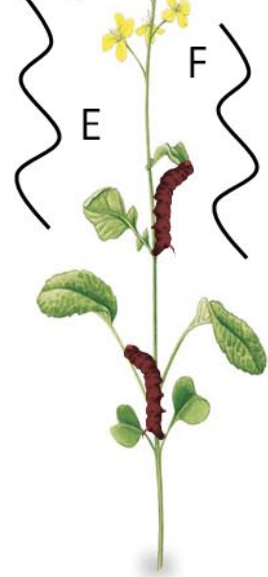

Novel response 